\title{
SSDL: A High-quality Icebox Watermelon Breeding Line Resistant to Fusarium Wilt and Anthracnose
}

\author{
J.M. Crall', G.W. Elmstrom ${ }^{2}$, and F.T. McCuistion, Jr. ${ }^{3}$ \\ University of Florida, Central Florida Research and Education Center, \\ Leesburg, FL 34748 \\ Additional index words. Citrullus lanatus, disease resistance, vegetable breeding
}

There is a continuing need for improved eating quality in watermelon [Citrullus lanatus (Thunb.) Matsum. \& Nakai]. The consumption of commercially produced watermelons fell from $8.1 \mathrm{~kg}$ per capita during the 10 years from 1951 to 1960 to $5.8 \mathrm{~kg}(28.5 \%$ decrease) for the 1971 to 1980 period. The icebox varieties 'Minilee' and 'Mickylee' (Crall, 1986) were released in 1986 to help overcome the decline or, perhaps, to reverse the trend. They are a convenient size for the consumer, and they are well adapted to shipment in cartons to domestic and foreign markets. With the release of these and other highquality, medium- to large-size varieties, the per capita consumption has increased (Allred and Lucier, 1990). In recent years, there has been a consumer preference for diploid and triploidhybrids (Maxwell, 1992; U.S. Dept. of Agriculture, 1993).

Consumer acceptance of the solid graygreen rind, characteristic of 'Minilee' and 'Mickylee', is declining (U.S. Dept. of Agriculture, 1993). Our purpose was to develop an icebox watermelon with stripes and an excellent internal quality that is suitable for use as a parent line in watermelon hybrids.

\section{Origin}

The germplasm used to develop SSDL, a small-seed 'Dixielee'-type, included 'Charleston Gray', 'Summit', 'Fairfax', Texas W-5, 'Crimson Sweet', and 'WR Graybelle' (Fig. 1). Wilt resistance came from Texas W-5 and 'Summit', and anthracnose resistance came from 'Fairfax', 'Charleston Gray', and 'Crimson Sweet'. High flesh quality came from Texas W-5 and 'Crimson Sweet', whereas small seed and fruit size came from 'Graybelle'. The original crosses leading to SSDL were made in 1961. The pedigree leading to J13-2 is the same as that of 'Minilee', 'Mickylee', and

Receivedforpublication 6 Nov. 1993. Accepted for publication 23 Nov. 1993. Univ. of Florida Agricultural Experiment Station Journal series paper R03 152. The cost of publishing this paper was defrayed in part by the payment of page charges. Under postal regulations, this paper therefore must be hereby marked advertisement solely to indicate this fact.

'Professor Emeritus.

${ }^{2}$ Professor of Horticulture.

${ }^{3} \mathrm{PhD}$ Graduate Assistant.
'Sugarlee' (Crall and Elmstrom, 198 1), varieties that all have very high fruit quality.

\section{Description}

The rind pattern of SSDL resembles that of 'Dixielee' (Crall and Elmstrom, 1979), having a narrow dark-green stripe on a light gray-green background (Fig. 2). Fruit are round to slightly oval, averaging 5 to $7 \mathrm{~kg}$ (large icebox size), and the flesh is dark red $44 \mathrm{D}$ as determined by Royal Horticultural Society color chart (Royal Horticultural Society, London). Rind thickness averages $8.2 \mathrm{~mm}$ and is thinner than that of 'Mickylee' (12.0 mm), 'Sugar Baby' (10.8 $\mathrm{mm})$, 'Jubilee II' (13.5 mm), and 'Charlee' $(15.2 \mathrm{~mm})$. However, the rind toughness is equal to that of 'Charlee' (Crall, 1990).

The seeds are mottled brown and about the same size (335 seeds/10 g) as those of 'Minilee' (360 seeds/10 g) but smaller than those of 'Mickylee' (250 seeds/10 g), 'Crimson Sweet' (224 seeds/10 g), or 'Jubilee' (86 seeds/10 g). Seed count per fruit of SSDL (222) is similar to that for 'Minilee' (214) and 'Mickylee' (212) but less than for 'Sugar Baby' (777), a similar-sized fruit; 'Crimson Sweet' (480); 'Jubilee II' (563); and 'Sunsweet' (922). A low number of seeds per unit weight is important so that the cut surface of the melon is attractive. Plant growth is vigorous; runner length and total expanse of individual plants are greater than 'Minilee' and less than for standard varieties such as 'Crimson Sweet'

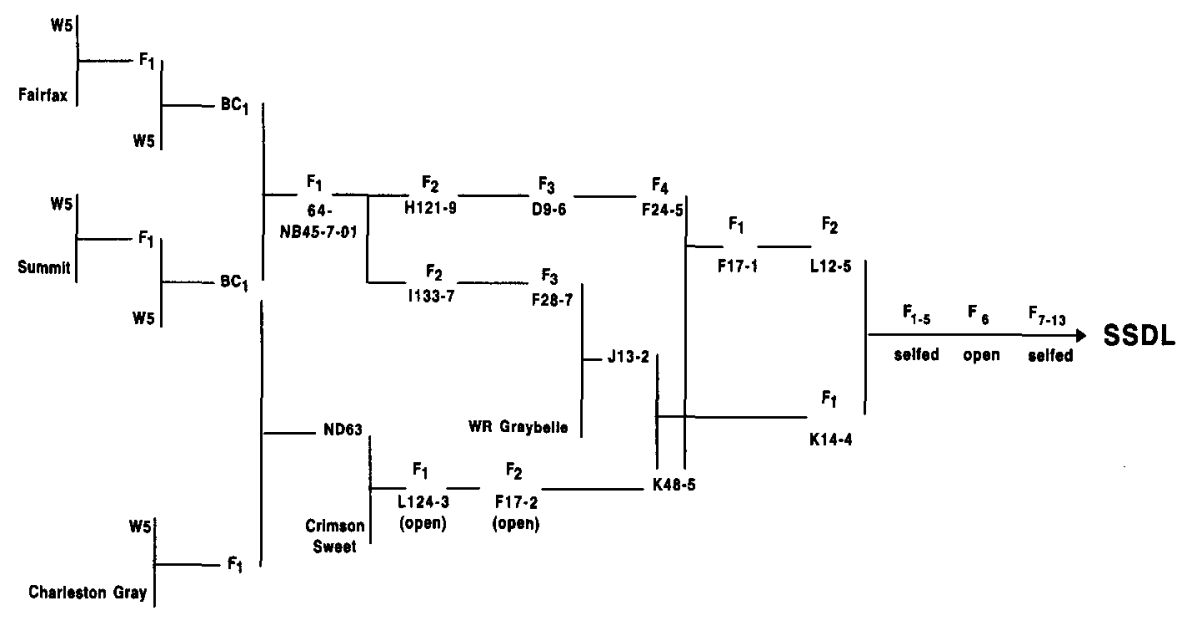

Fig. 1. Pedigree of SSDL watermelon. lar to 'Crimson Sweet' and 'Charleston Gray'
Although anthracnose resistance has not been documented in SSDL, breeding lines from which SSDL was developed were resistant to race 1 anthracnose [Colletotrichum orbiculare (Berk. \& Mont.)] in greenhouse inoculation tests. SSDL is also resistant to races 0 and 1 fusarium wilt [Fusarium oxysporum f. sp. niveum (E. F. Sm.) Snyd. \& Hans.]. All 'New Hampshire Midget' had wilt when grown in the greenhouse in soil infested with 1000 to 1200 propagules of fusarium wilt (race 1), whereas $63.3 \%$ of 'Charleston Gray' had wilt; 'Calhoun Gray' and SSDL had no wilt.

At the Univ. of Florida Gulf Coast Research and Education Center, Bradenton, in 1989 and 1990, SSDL had a higher soluble solids concentration (SSC) than any of the other icebox entries (Table 1) (Maynard, 1989, 1990). In 1989, total yield was second only to the $\mathrm{F}_{1}$ icebox variety 'Tiger Baby'. Mean fruit weight was 5 to $6 \mathrm{~kg}$, slightly more than that of the other icebox entries in the trials. SSDL does not mature as early as 'Minilee' and 'Mickylee'; it ripens in midseason and is simiin that respect.

SSDL was an observational entry in the Southern Cooperative Watermelon Trials in 1983-85. In 1983, SSDL had a higher yield and a higher SSC than 'Petite Sweet' over 16 locations (Table 2) (C.E. Johnson, Chairman, 1983-85 Southern Cooperative Watermelon Trials, Louisiana Agricultural Experiment Station, Calhoun). In 1984 and 1985, SSDL had a higher SSC than 'Sugar Baby'. In 1984, total yields for SSDL and 'Sugar Baby' were about equal; in 1985 SSDL outyielded 'Sugar Baby'.

\section{Summary}

SSDL is a large icebox variety with an attractive striped rind pattern, good internal red pigmentation, and a higher SSC than other icebox varieties. The small seed size and low seed count render the cut fruit appealing to the consumer. Although the rind is thin, it is tough. The characteristics noted should make SSDL an excellent parent in hybrid crosses, especially when making triploid seed. SSDL could be crossed with a small parent to produce an 


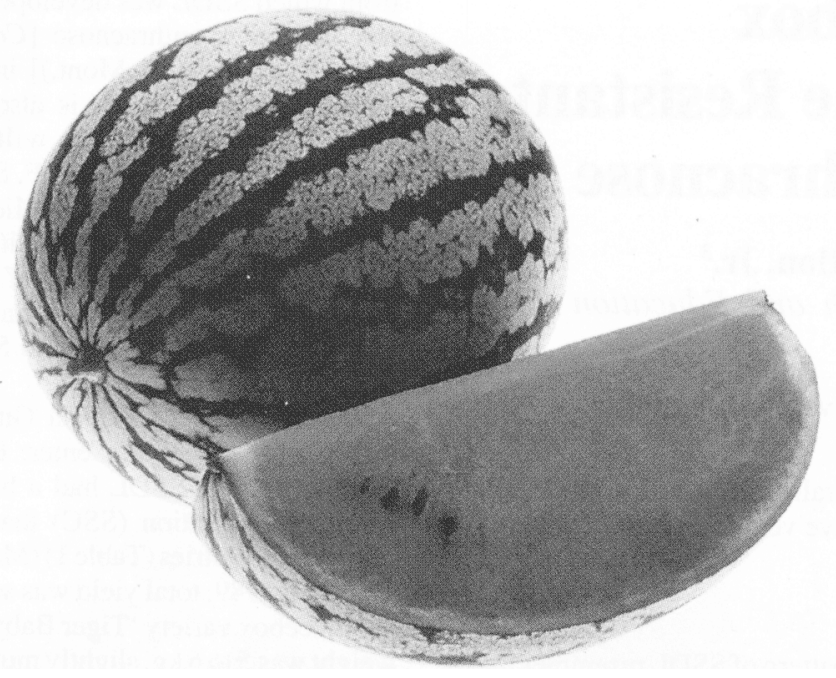

Table 2. Marketable yields, melon weights, and soluble solids concentration (SSC) of juice for icebox watermelons in the Southern Cooperative Watermelon Observational Trials for 1983 1984 , and 1985.

\begin{tabular}{lccr}
\hline \hline Variety & $\begin{array}{c}\text { Yield } \\
\left(\mathrm{t} \cdot \mathrm{ha}^{-1}\right)\end{array}$ & $\begin{array}{c}\text { Mean fruit } \\
\text { wt }(\mathrm{kg})\end{array}$ & $\begin{array}{r}\text { SSC } \\
(\%)\end{array}$ \\
\hline SSDL & $1.983(16$ locations $)$ \\
Petite Sweet & 18.1 & 5.7 & \\
& 15.2 & 4.6 & 11.4 \\
SSDL & $1984(15$ locations $)$ & \\
Sugar Baby & 24.8 & 6.3 & 11.6 \\
& 26.0 & 4.3 & 9.8 \\
SSDL & $1985(7$ locations $)$ & \\
Sugar Baby & 22.2 & 5.8 & 11.3 \\
\hline
\end{tabular}

\section{Literature Cited}

Allred, A.J. and G. Lucier. 1990. The U.S. watermelon industry. Commodity Economics Div., Economic Res. Serv., U.S. Dept. Agr., Staff Rpt. AGES 9015.

Fig. 2. Fruit of SSDL watermelon.

Table 1. Marketable yields, melon weights, and soluble solids concentration (SSC) of juice for icebox watermelon varieties at Bradenton., Fla.

\begin{tabular}{|c|c|c|c|c|c|c|}
\hline \multirow[b]{2}{*}{ Variety } & \multicolumn{2}{|c|}{$\begin{array}{c}\text { Yield } \\
\left(\text { toha } a^{-1}\right)\end{array}$} & \multicolumn{2}{|c|}{$\begin{array}{c}\text { Mean fruit } \\
\text { wt (kg) }\end{array}$} & \multicolumn{2}{|c|}{$\operatorname{SSC}(\%)$} \\
\hline & 1989 & 1990 & 1989 & 1990 & 1989 & 1990 \\
\hline$\overline{\text { SSDL }}$ & $55.2 a-c^{2}$ & $31.3 \mathrm{de}$ & $4.9 \mathrm{ab}$ & $5.7 \mathrm{a}$ & $12.9 \mathrm{a}$ & $11.7 \mathrm{a}$ \\
\hline Mickylee & $50.7 \mathrm{bc}$ & $67.4 \mathrm{a}$ & $3.9 a-c$ & $4.9 \mathrm{ab}$ & $11.3 \mathrm{bc}$ & $10.7 b-d$ \\
\hline Minilee & $45.0 \mathrm{~cd}$ & $41.7 \mathrm{~cd}$ & $2.9 \mathrm{~d}$ & $3.5 \mathrm{c}$ & $11.5 \mathrm{~b}$ & $11.4 \mathrm{ab}$ \\
\hline Sugar Baby & $31.9 \mathrm{~d}$ & $53.8 \mathrm{a}-\mathrm{c}$ & $3.6 \mathrm{~b}-\mathrm{d}$ & $4.4 \mathrm{bc}$ & $10.9 \mathrm{bc}$ & $10.2 \mathrm{~d}$ \\
\hline Southern Belle & $50.1 \mathrm{bc}$ & $67.1 \mathrm{a}$ & $4.0 \mathrm{bc}$ & $5.4 \mathrm{ab}$ & $10.7 \mathrm{c}$ & $10.5 \mathrm{~cd}$ \\
\hline Baby Gray $F_{1}$ & $48.7 \mathrm{bc}$ & $49.9 \mathrm{bc}$ & $3.1 \mathrm{~d}$ & $3.6 \mathrm{c}$ & $11.3 \mathrm{bc}$ & $11.5 \mathrm{ab}$ \\
\hline Tiger Baby $\mathrm{F}_{1}$ & $70.2 \mathrm{a}$ & $61.5 \mathrm{ab}$ & $4.1 \mathrm{~b}$ & $4.4 \mathrm{bc}$ & $11.4 \mathrm{bc}$ & $11.1 \mathrm{a}-\mathrm{c}$ \\
\hline
\end{tabular}

${ }^{2}$ Mean separation within columns by Duncan's multiple range test, $P=0.05$.

icebox-sized fruit or with a large-fruited variety to produce a standard-sized fruit.

\section{Seed availability}

The Florida Agricultural Experiment Station has requested-plant variety protection for
SSDL from the Plant Variety Protection Office of the U.S. Dept. of Agriculture. Inquiries regarding seed availabilit and the use of this line in F, hybrid seed production should be directed to the Florida Foundation Seed Producers, P.O. Box 309, Greenwood, FL 32443.
Crall, J.M. 1986. 'Minilee' and 'Mickylee', two icebox-type watermelon cultivars with excellent fruit quality and resistance to both anthracnose and fusarium wilt. Fla. Agr. Expt. Sta. Circ. S-336.

Crall, J.M. 1990. 'Charlee' watermelon. HortScience 25:812-813.

Crall, J.M. and G.W. Elmstrom. 1979. 'Dixielee', a round, striped watermelon with intense red flesh and resistance to anthracnose and fusarium wilt. Fla. Agr. Expt. Sta. Circ. S-263.

Crall, J.M. and G.W. Elmstrom. 1981. 'Sugarlee', an early, high quality, disease resistant watermelon variety for Florida commercial growers. Fla. Agr. Expt. Sta. Circ. S-277.

Maxwell, K. 1992. Aiton: Seedless safes "exploding". The Produce News. 2 May 1992, p. 23.

Maynard, D.N. 1989. Icebox watermelon variety evacuation Spring 1989. Bradenton Gulf Coast Res. \& Educ. Ctr. Res. Rpt. BRA1989-11.

Maynard, D.N. 1990. Icebox watermelon variety evaluation Spring 1990. Bradenton Gulf Coast Res. \& Educ. Ctr. Res. Rpt. BRA1990-14.

U.S. Dept. of Agriculture. 1993. Marketing watermelons 1992 crop. Federal-State Market News Serv., Thomasville, Ga. 